\title{
KEWENANGAN KEPALA KUA SEBAGAI WALI HAKIM MENURUT PERATURAN MENTERI AGAMA NO. 30 TAHUN 2005
}

\author{
Ikhsan Harjanto \\ Munifah \\ Universitas Nahdlatul Ulama Surakarta
}

\begin{abstract}
Abstrak
Penelitian ini bertujuan untuk mengetahui kewenangan Kepala KUA sebagai wali nikah. Jenis penelitian ini adalah penelitian yang bersifat deskriptif. Metode analisis yang dipergunakan oleh penulis dalam penelitian ini adalah metode kualitatif. Pengumpulan data dalam penelitian penulis mulai berusaha untuk menarik kesimpulan berdasarkan semua hal bersama-sama dalam reduksi data dan sajian datanya tersebut. Hasil penelitian menunjukkan, prosedur pelaksanaan perkawinan oleh kepala KUA sebagai wali hakim terhadap calon mempelai wanita yang walinya adhol menurut PMA No 30 tahun 2005 adalah calon pengantin wanita dan pria datang ke KUA kecamatan tempat tinggal pengantin wanita dengan membawa berkas persyaratan pernikahan untuk memberitahukan kehendak nikah, jika tidak terdapat keterangan wali nikah, Kepala KUA memanggil wali dengan surat diupayakan 3 (tiga) kali dengan berita acara pemanggilan
\end{abstract}

Kata kunci: Kepala KUA, Wali Nikah

\section{Abstract}

This research aims to discover the authority of the Head of KUA as a guardian of marriage. This type of research is descriptive research. The analytical method used by the authors in this study is the qualitative method. Data collection in the author's research began to attempt to draw conclusions based on all things together in reducing the data and the 
presentation of the data. The results of the study showed, the procedure of marriage implementation by the head of KUA as a guardian of the judge against the bride-to-be whose guardian is adhol according to PMA No. 30 of 2005, is the bride and groom come to KUA district where the bride lives by bringing a file of marriage requirements to inform the marriage request. If there is no description of the guardian of marriage, the Head of KUA calls the guardian with a letter attempted 3 (three) times with news of the call event.

Keywords: Head of KUA, Guardian of Marriage

\section{A. PENDAHULUAN}

Perkawinan merupakan sarana makhluk Allah SWT untuk melestarikan generasi yang akan datang. Hal ini terjadi bagi manusia, hewan dan tumbuhan. Manusia adalah makhluk yang sempurna dan mempunyai peradaban yang sangat tinggi. Agar kelangsungan hidupnya berkembang dengan baik, Islam telah melarang untuk melepaskan nafsu seksualnya pada jalan yang bukan tempatnya, yang tidak diridhai Allah SWT, misalnya zina Homoseksual, Lesbian dan sebagainya. Islam telah membuka jalan keluarnya untuk menyalurkan nafsu seksualnya dijalan yang telah ditetapkan syariatnya yaitu perkawinan. Perkawinan merupakan salah satu sunnatullah untuk membina hidup sejahtera lahir dan batin.

Allah SWT menganugerahkan kepada manusia hidup berpasang pasangan supaya dalam mengadakan perkawinan bisa berkembang biak untuk melestarikan generasi atau keturunannya yang membentuk kelompok bersuku suku dan berbangsa bangsa sebagaimana yang diajarkan agama Islam serta diharuskan dengan lawan jenis agar merasa bahagia dan sejahtera bukan sejenis homo atau lesbian yang hanya menururuti hawa nafsunya.

Islam sangat menganjurkan bagi setiap manusia yang mampu, berakal, dewasa untuk melestarikan keturunan yang sah, dengan melakukan perkawinan yang sah dan tercatat agar tidak terjadi pembauran keturunan yang berakibat terjadi percecokan atau perseteruan antar garis keturunan.

Suami istri sebagai suatu keluarga merupakan dasar pembentukan 
kelompok dalam masyarakat yang akhirnya membentuk bangsa dan negara.' Hubungan suami istri dalam berumah tangga harus langgeng penuh kebahagiaan lahir dan batin, jasmani dan rohani, material maupun spiritual yang dilandasi dengan saling menghormati atau tasamuh, rasa aman dan tentram atau sakinah, saling mencintai atau mawaddah dan saling menyayangi atau rahmah.

Undang-undang Nomor 1 Tahun 1974 tentang Perkawinan Pasal 1 dinyatakan, "perkawinan ialah ikatan lahir batin antara seorang pria dan seorang wanita sebagai suami istri dengan tujuan membentuk keluarga atau rumah tangga yang bahagia dan kekal berdasarkan Ketuhanan Yang Maha Esa". Menurut ketentuan tersebut diatas perkawinan baru ada apabila dilakukan antara seorang pria dan seorang wanita, namun apabila dilakukan oleh dua orang pria saja (homo seksual) ataupun dua orang wanita saja (lesbian) maka hal tersebut tidak dapat dikatakan perkawinan.

Setiap orang yang melangsungkan perkawinan harus berlainan jenis yang sesuai dengan agama dan kepercayaanya serta dicatat dalam peraturan perundang-undangan yang berlaku. Perundang-undangan yang dimaksud adalah: Undang-undang Nomor 1 Tahun 1974 tentang Perkawinan, Peraturan Pemerintah Nomor 9 Tahun 1975 tentang Pelaksanaan Undangundang RI Nomor 1 Tahun 1974, dan PMA Nomor 11 tahun 2007 tentang Pencatatan Nikah.

Di dalam peraturan perundangan tersebut dijelaskan antara lain mengenai pengertian, tujuan, dasar, syarat, dan tata cara pemberitahuan kehendak nikah. ${ }^{3}$ Untuk melaksanakan perkawinan harus ada calon suami, calon istri, wali nikah, ijab dan Kabul. Wali nikah dalam perkawinan merupakan rukun yang harus dipenuhi bagi calon mempelai wanita yang bertindak untuk menikahkannya. Wali nikah terdiri dari wali nasab, dan wali hakim. ${ }^{4}$

Perkawinan adalah "sah apabila dilakukan menurut hukum masing-

${ }^{1}$ Ash-Shabuni, M, Nikah, Kenapa Mesti Ditunda?, (Bandung: Hikmah Kelompok Mizan, 2004), hal. 12

2 Zaenal Fatah dkk, Himpunan Peraturan Kepenghuluan, (Semarang: Kantor Wilayah Kementerian Agama Propinsi Jawa Tengah, 2013), hal. 18.

${ }^{3}$ Hasil wawancara langsung dengan Bapak Sadali, Kepala Kantor Urusan Agama Kecamatan Ceper tanggal 8 Nopemberr 2016

${ }^{4}$ Inpres RI Nomor I Tahun 1991, Kompilasi Hukum Islam Di Indonesia, (Jakarta: Departemen Agama RI, 2000), Cet. I, hal. 20. 
masing agamanya dan kepercayaanya itu".s Bagi orang Islam yang nikah tanpa adanya wali, perkawinannya dianggap tidak sah.

Wali nasab adalah "Pria beragama Islam yang mempunyai hubungan darah dengan calon mempelai wanita dari pihak ayah menurut hukum Islam"' artinya anggota keluarga laki-laki dari calon mempelai perempuan yang mempunyai hubungan darah garis bapak dengan calon mempelai perempuan. Jadi termasuk wali nasab ialah ayah, kakek, saudara laki-laki, paman dan seterusnya.

Wali hakim adalah Kepala Kantor Urusan Agama Kecamatan yang ditunjuk oleh Menteri Agama untuk bertindak sebagai wali nikah bagi calon mempelai wanita yang tidak mempunyai wali.' Wali hakim baru dapat bertindak sebagai wali nikah apabila wali nasab tidak ada atau tidak mungkin menghadirkannya atau tidak diketahui tempat tinggalnya atau ghaib atau adhol atau enggan.

Wali adhol adalah penolakan wali untuk menikahkan anak perempuannya yang berakal dan sudah baligh dengan laki-laki yang sepadan dengan perempuan itu. Jika perempuan tersebut telah memintanya (kepada walinya) untuk dinikahkan dan masing-masing calon mempelai itu saling mencintai, maka penolakan demikian menurut syara' dilarang.

Ijab dilaksanakan oleh wali nasab yang bersangkutan, namun demikian wali bisa mewakilkan kepada petugas pegawai pencatat nikah atau orang lain yang menurut pegawai pencatat nikah telah memenuhi syarat peraturan perundangan dan hukum Islams. Kenyataan dalam suatu perkawinan, tidak setiap calon mempelai wanita mempunyai wali nasab. Maka sangat perlu diupayakan dan dimusyawarahkan antara calon mempelai, orang tua, dan yang terkait dengan perkawinan tentang masalah yang dihadapi dalam hal ini nikahnya, sehingga masalah yang dihadapi dapat diselesaikan dengan baik dan benar.

Tujuan pernikahan untuk membentuk keluarga yang bahagia dan

${ }^{5}$ Undang-Undang Nomor 1 Tahun 1974 pasal 2 ayat 1, Lihat Zaenal Fatah dkk, Himpunan Peraturan Kepenghuluan, (Semarang: Kantor Wilayah Kementerian Agama Propinsi Jawa Tengah, 2013), hal. 18.

${ }^{6}$ Peraturan Menteri Agama Republik Indonesia Nomor 30 Tahun 2005 pasal 1 ayat 1.

${ }^{7} \mathrm{Ibid}$,

${ }^{8}$ PMA RI Nomor 11 Tahun 2007, Lihat Zaenal Fatah dkk, Himpunan Peraturan Kepenghuluan, (Semarang: Kantor Wilayah Kementerian Agama Propinsi Jawa Tengah, 2013), hal. 82. 
kekal, sakinah mawadah dan rahmah bisa terwujud. Di dalam praktik pelaksanaan nikah, kadang-kadang orang tua, kerabat atau keluarga merasa berhak menjadi wali nikah dalam perkawinan calon mempelai wanita dengan alasan yang bermacam-macam. Misal ada bukti akta kelahirannya, masuk dalam kartu keluarganya dan sebagainya. Padahal dia tidak berhak menjadi wali nikah dari calon mempelai wanita itu atau sebaliknya dia berhak menjadi wali nikah namun ia enggan atau tidak mau menikahkannya. Wali nasab adalah "Pria beragama Islam yang mempunyai hubungan darah dengan calon mempelai wanita dari pihak ayah menurut hukum Islam" artinya anggota keluarga laki-laki dari calon mempelai perempuan yang mempunyai hubungan darah garis bapak dengan calon mempelai perempuan. Jadi termasuk wali nasab ialah ayah, kakek, saudara laki-laki, paman dan seterusnya. Peraturan Menteri Agama Republik Indonesia Nomor 30 Tahun 2005 dijelaskan, bagi calon mempelai wanita yang tidak mempunyai wali, maka pernikahannya dilangsungkan oleh wali hakim. "Wali hakim adalah Kepala Kantor Urusan Agama Kecamatan yang ditunjuk oleh Menteri Agama untuk bertindak sebagai wali nikah bagi calon mempelai wanita yang tidak mempunyai wali". ${ }^{10}$

Akad nikah (Ijab) dilaksanakan oleh wali nasab yang bersangkutan. Namun demikian wali bisa mewakilkan kepada petugas Pegawai Pencatat Nikah atau orang lain yang menurut Pegawai Pencatat Nikah telah memenuhi syarat peraturan perundangan dan hukum Islam." Kenyataan dalam suatu perkawinan, tidak setiap calon mempelai wanita mempunyai wali nasab. Maka sangat perlu diupayakan dan dimusyawarahkan antara calon mempelai, orang tua, dan yang terkait dengan perkawinan tentang masalah yang dihadapi dalam hal ini nikahnya. Sehingga masalah yang dihadapi dapat diselesaikan dengan baik dan benar.

Tujuan pernikahan untuk membentuk keluarga yang bahagia dan kekal berdasarkan Ketuhanan Yang Maha Esa sakinah mawadah dan rahmah bisa terwujud. Di dalam praktik pelaksanaan nikah, ada orang tua, kerabat

${ }_{9}^{9}$ Peraturan Menteri Agama Republik Indonesia Nomor 30 Tahun 2005 pasal 1 ayat 1.

${ }^{10}$ Ibid., ayat 2.

11 PMA RI Nomor 30 Tahun 2005, Lihat Zaenal Fatah dkk, Himpunan Peraturan Kepenghuluan, (Semarang: Kantor Wilayah Kementerian Agama Propinsi Jawa Tengah, 2013), hal. 82 . 
atau keluarga yang berhak secara nasab menjadi wali nikah dalam perkawinan calon mempelai wanita menolak menjadi wali dengan alasan yang bermacam-macam atau dalam bahasa lain enggan (adhol) tidak mau menjadi wali dalam pernikahan tersebut. Sehingga perlu adanya tindakan dalam upaya pernikahan syah menurut hukum Islam dengan upaya tertentu termasuk mengupayakan lewat jalur pengadilan, kemudian yang akhirnya wali yang seharusnya nasab menjadi Wali adhol. Adhol-nya wali merupakan salah satu syarat atau keadaan dibolehkannya wali hakim sebagai wali dalam perkawinan calon mempelai perempuan dengan calon mempelai laki-laki. Untuk menyatakan adhol-nya seorang wali, maka diperlukan penetapan dari Pengadilan Agama/ Mahkamah Syar'iyah yang mewilayahi tempat tinggal calon mempelai wanita.

Perkawinan adalah "Ikatan lahir batin antara seorang pria dan seorang wanita sebagai suami istri dengan tujuan membentuk keluarga atau rumah tangga yang bahagia dan kekal berdasarkan Ketuhanan Yang Maha Esa". ${ }^{2}$ Dari perumusan tersebut dapat disimpulkan bahwa perkawinan itu mengandung beberapa unsur yaitu:

1. Ikatan lahir batin

2. Adanya seorang pria dan seorang wanita.

3. Membentuk keluarga bahagia

4. Dalam waktu tak terbatas atau kekal.

5. Berdasarkan kepada Tuhan Yang Maha Esa.

Bahwa perkawinan itu tidak cukup hanya dengan adanya suatu ikatan lahir atau ikatan batin saja, akan tetapi harus ada kedua unsur tersebut" Ikatan lahir yaitu ikatan yang dapat dilihat. Ikatan lahir ini berupa hubungan yang sah untuk hidup sebagai suami istri. Sebaliknya ikatan batin adalah ikatan yang tidak dapat dilihat. Tanpa adanya ikatan batin yang mendasari suatu perkawinan maka tidak akan ada artinya dan tidak ada jaminan perkawinan itu berlangsung secara utuh dan langgeng.

${ }^{12}$ Undang-Undang Nomor 1 Tahun 1974 Pasal 1, Lihat Zaenal Fatah dkk, Himpunan Peraturan Kepenghuluan, (Semarang : Kantor Wilayah Kementerian Agama Propinsi Jawa Tengah, 2013), hal. 18.

${ }^{13}$ Soenaryo, Hukum Adat II, (Surakarta: Buku Pegangan Kuliah Fakultas Hukum Universitas Sebelas Maret, 1993), hal. 19. 
Ikatan lahir batin dalam suatu perkawinan merupakan faktor yang sangat penting karena perpaduan antara ikatan lahir dan ikatan batin akan menjadi fondasi yang kuat dalam membentuk dan membina keluarga yang bahagia dan kekal.

Kompilasi Hukum Islam menjelaskan pengertian perkawinan adalah "Aqad yang sangat kuat atau mitsaqan ghalidzan untuk mentaati perintah Allah dan melaksanakannya merupakan ibadah". ${ }^{4}$ Pengertian perkawinan menurut hukum Islam adalah Nikah.

Nikah adalah suatu perjanjian atau aqad (ijab dan qabul) antara seorang laki-laki dan perempuan untuk menghalalkan hubungan badaniyah sebagaimana suami istri yang sah yang mengandung syarat-syarat dan rukun-rukun yang ditentukan oleh syariat agama Islam ${ }^{15}$ dan peraturan perundang-undangan. Nikah yaitu melakukan suatu aqad atau perjanjian untuk mengikatkan diri antara seorang laki-laki dan seorang wanita untuk menghalalkan hubungan kelamin antara kedua belah pihak, dengan dasar sukarela dan keridhoan kedua belah pihak untuk mewujudkan suatu kebahagiaan hidup berkeluarga yang diliputi rasa kasih sayang dan ketentraman dengan cara-cara yang diridhoi oleh Allah. ${ }^{16}$

Pengertian perkawinan menurut Kompilasi Hukum Islam dan menurut hukum Islam tersebut dapat dijelaskan bahwa perkawinan adalah ibadah, termasuk dalam rangka menaati agama (Sunnatullah dan Sunnah Nabi Muhammad $S A W$ ). Didalam pengertian tersebut dikatakan bahwa pernikahan merupakan suatu perjanjian atau aqad, perjanjian yang sangat kuat atau mitsaqan ghalidzan untuk membentuk keluarga antara seorang pria dengan seorang wanita menjadi suami istri yang sah. "Perkawinan itu tidak hanya sebagai suatu perjanjian biasa melainkan suatu perjanjian suci dimana kedua belah pihak dihubungkan menjadi pasangan suami istri..7

Perwalian dalam istilah Fiqh disebut wilayah yang berarti penguasaan dan perlindungan. Jadi arti dari perwalian menurut Fiqh adalah penguasaan

${ }^{14}$ Instruksi Presiden RI Nomor 1 Tahun 1991, Kompilasi Hukum Islam Di Indonesia, (Jakarta: Departemen Agama RI, 2000), hal. 14.

${ }^{15}$ Asrorun Ni'am Sholeh, Fatwa-Fatwa Masalah Pernikahan dan Keluarga, (Jakarta: elSAS, 2008), Cet. I, hal. 3.

${ }_{16}$ Ahmad Azhar Basyir, Hukum Perkawinan Islam, (Yogyakarta: Fakultas Hukum Universitas Islam Indonesia, 1977), hal. 10.

${ }_{17}$ Soemiyati, Hukum Perkawinan Islam dan Undang-Undang Perkawinan (Undang-Undang Nomor 1 Tahun 1974), (Yogyakarta, Liberty, 1982), hal. 12. 
penuh yang diberikan oleh agama kepada seseorang untuk menguasai atau melindungi orang atau barang. Penguasaan dan perlindungan ini disebabkan oleh:

1. Pemilikan atas barang atau orang, seperti perwalian atas budak yang dimiliki atau barang-barang yang dimiliki.

2. Hubungan kerabat atau keturunan, seperti perwalian seseorang atas salah seorang kerabatnya atau anak-anaknya.

3. Karena memerdekakan budak, seperti perwalian seseorang atas budak-budak yang telah dimerdekakannya.

4. Karena pengangkatan, seperti perwalian seorang kepala negara atas rakyatnya atau perwalian seorang pemimpin atas orang-orang yang dipimpinnya. ${ }^{18}$

Dalam garis besarnya perwalian dapat dibagi atas:

1. Perwalian atas orang.

2. Perwalian atas barang.

3. Perwalian atas orang dalam perkawinan.

Dari bermacam-macam perwalian diatas, yang dibicarakan disini adalah perwalian dalam perkawinan seseorang dalam pelaksanaan pernikahan atau sebagai wali nikah. Wali yang dimaksudkan dalam Pasal 6 Undang-undang Nomor 1 Tahun 1974 adalah wali yang akan memberikan ijin untuk melangsungkan perkawinan. Adapun ijin perkawinan dapat diberikan oleh orang tua yang masih hidup jika salah satu meninggal dunia. Akan tetapi wali/ ibu itu tidak dapat bertindak sebagai wali nikah karena untuk dapat menjadi wali nikah salah satu syaratnya yaitu seorang laki-laki, seperti yang penulis jelaskan dalam uraian syarat-syarat wali nikah. Dengan demikian dapat dijelaskan bahwa wali nikah ialah seorang laki-laki yang memenuhi syarat hukum Islam yang bertindak menikahkan calon mempelai wanita. ${ }^{19}$

Wali dalam perkawinan adalah rukun artinya harus ada dalam perkawinan. Undang-undang Nomor 1 Tahun 1974 Pasal 2 ayat (1)

\footnotetext{
${ }^{18}$ Soemiyati, Op., Cit., hal. 41.

${ }_{19}$ Intruksi Presiden RI Nomor 1 Tahun 1991, Lihat Kompilasi Hukum Islam Di Indonesia, (Jakarta: Departemen Agama RI, 2000), Pasal 20 ayat 1. hal. 20.
} 
disebutkan bahwa perkawinan itu sah apabila dilakukan menurut hukum masing-masing agamanya dan kepercayaannya itu. Maka sahnya perkawinan menurut hukum Islam ditentukan antara lain dengan adanya wali nikah. Tanpa wali nikah perkawinan itu tidak sah.

Menurut Kompilasi Hukum Islam, wali nikah terdiri dari wali nasab dan wali hakim. Wali nasab terdiri dari empat kelompok dalam urutan kedudukan. Kelompok yang satu didahulukan dan kelompok yang lain sesuai erat tidaknya susunan kekerabatan dengan calon mempelai wanita. Empat kelompok tersebut adalah sebagai berikut:

Pertama, kelompok kerabat laki-laki garis lurus keatas yakni ayah, kakek dari pihak ayah dan seterusnya. Kedua, kelompok kerabat saudara laki-laki kandung atau saudara laki-laki seayah, dan keturunan laki-laki mereka. Ketiga, kelompok kerabat paman, yakni saudara laki-laki kandung ayah, saudara seayah dan keturunan laki-laki mereka. Keempat, kelompok saudara laki-laki kandung kakek, saudara laki-laki seayah kakek dan keturunan laki-laki mereka. ${ }^{20}$

Wali nikah yang paling berhak, urutannya tidak memenuhi syarat sebagai wali nikah atau oleh karna wali nikah itu menderita tuna wicara, tuna rungu atau sudah udzur, maka hak menjadi wali bergeser kepada wali nikah yang lain menurut derajat berikutnya. Wali hakim baru dapat bertindak sebagai wali nikah apabila wali nasab tidak ada atau tidak mungkin menghadirkannya atau tidak diketahui tempat tinggalnya atau ghaib atau adhol atau enggan. ${ }^{21}$

Di dalam hukum perkawinan Islam, bahwa wali salah satu rukun perkawinan dan tak ada perkawinan, kalau tak ada wali. Oleh sebab itu perkawinan yang dilakukan dengan tiada berwali hukumnya tidak sah. Macam-macam wali dalam perkawinan, antara lain sebagai berikut:

1. Wali Nasab.

Wali nasab artinya anggota keluarga laki-laki dari calon mempelai perempuan yang mempunyai hubungan darah patrilinial dengan calon mempelai perempuan.

${ }^{20}$ Intruksi Presiden RI Nomor 1 Tahun 1991, Op. Cit., hal. 21.

${ }^{21}$ Ibid., hal. 22. 
2. Wali hakim

Peraturan Menteri Agama Republik Indonesia Nomor 30 Tahun 2005 Tentang Wali Hakim. Pasal 1 ayat (2) Wali hakim, adalah Kepala Kantor Urusan Agama Kecamatan yang ditunjuk oleh Menteri Agama untuk bertindak sebagai wali nikah bagi calon mempelai wanita yang tidak mempunyai wali. Pasal 2 ayat (1) Bagi calon mempelai wanita yang akan menikah di wilayah Indonesia atau di luar negeri/di luar wilayah territorial Indonesia, tidak mempunyai wali nasab yang berhak atau wali nasabnya tidak memenuhi syarat, atau mafqud (tidak tentu keberadaanya), atau berhalangan, atau adhol, maka pernikahannya dilangsungkan oleh wali hakim. Pasal 2 ayat (2) Khusus untuk menyatakan adhalnya wali sebagaimana tersebut pada ayat (1) pasal ini ditetapkan dengan keputusan Pengadilan Agama/ Mahkamah Syar'iyah yang mewilayahi tempat tinggal calon mempelai wanita. ${ }^{22}$

Instruksi Presiden RI Nomor 1 tahun 1991 tentang Kompilasi hukum Islam. Pasal 23, wali hakim baru dapat bertindak sebagai wali nikah apabila wali nasab tidak ada atau tidak mungkin menghadirkannya atau tidak diketahui tempat tinggalnya atau ghaib atau adhol atau enggan. Dalam hal wali adhol atau enggan maka wali hakim dapat bertindak sebagai wali nikah setelah ada putusan Pengadilan Agama tentang wali tersebut. ${ }^{23}$

Syarat-syarat dan rukun sahnya perkawinan atau nikah menurut hukum Islam dan peraturan perundang-undangan, wali nikah adalah hal yang sangat penting dan menentukan sah tidaknya pernikahan. Apabila masih ada empat kelompok wali nasab tersebut dalam tata urutan wali nikah, maka dialah yang berhak menjadi wali nikah. Namun kenyataan dalam suatu perkawinan, tidak semua calon mempelai wanita mempunyai keempat kelompok yang berhak menjadi wali nikah, mungkin tidak mempunyai wali nasab yang berhak atau wali nasabnya tidak memenuhi syarat atau mafqud (tidak tentu keberadaanya) atau berhalangan atau adhol, berdasarkan Pasal 2 ayat (1) PMA Nomor 30 Tahun 2005 dan pasal 23 Instruksi Presiden RI

\footnotetext{
${ }^{22}$ Zaenal Fatah dkk., Op. Cit., hal. 94.

${ }^{23}$ Lihat Intruksi Presiden RI Nomor 1 Tahun 1991, Kompilasi Hukum Islam Di Indonesia, (Jakarta: Departemen Agama RI, 2000), hal. 22.
} 
Nomor 1 Tahun 1991 tentang Kompilasi Hukum Islam di Indonesia, maka pernikahannya dilangsungkan oleh wali hakim.

Pelaksanaan Perkawinan Dengan Wali Hakim, ${ }^{24}$ apabila wali nasab tidak ada atau tidak memenuhi syarat, atau mafqud, atau adhol, maka pihak yang akan melangsungkan perkawinan atau wakilnya mengajukan surat permohonan wali hakim kepada kepala desa di desa tempat tinggal calon mempelai wanita dan surat-surat lain yang ditentukan oleh peraturan perundang-undangan. Dengan membawa surat-surat tersebut kemudian menyampaikan kehendak nikah ke Pegawai Pencatat Nikah atau Kepala Kantor Urusan Agama. Kemudian Pegawai Pencatat Nikah atau Kepala Kantor Urusan Agama memeriksa surat-surat tersebut dan membuktikan kebenaran alasan-alasan permohonan wali hakim. Apabila dari hasil pemeriksaan ternyata memang benar alasan permohonan wali hakim tersebut, maka kemudian dilihat wali hakim yang dimohonkan itu disebabkan oleh apa. Wali nasab pindah kepada wali hakim apabila:

1. Wali nasab habis/ tidak ada, atau

2. Wali nasab bepergian jauh atau tidak ada di tempat (masafatul qosri), atau wali nasab ada tetapi tidak memenuhi syarat, atau

3. Wali berada dalam penjara atau tahanan yang tidak boleh dijumpai, atau

4. Wali nasab sedang berihram haji/ umrah, atau

5. Wali adhol, artinya wali tidak bersedia/menolak untuk menikahkan atau

6. Wali mafqud, artinya tidak tentu/tidak jelas keberadaannya.

Apabila dalam suatu perkawinan terdapat suatu keadaan seperti tersebut di atas, maka yang berhak menjadi wali nikah di dalam perkawinan tersebut adalah wali hakim (PMA Nomor 30 Tahun 2005 Pasal 2 ayat 1), dalam hal ini adalah Kepala Kantor Urusan Agama Kecamatan (PMA Nomor 30 Tahun 2005 Pasal 1 ayat 2). Apabila yang menyebabkan adanya perkawinan dengan wali hakim itu karena adholnya wali nasab, maka yang berhak menetapkan adholnya wali, hanya Pengadilan Agama (PMA Nomor

${ }^{24}$ Hasil wawancara dengan Kepala Kantor Urusan Agama Kecamatan Sambi dan staf tanggal 17 Nopember 2014. 
30 Tahun 2005 Pasal 2 ayat 2, Instruksi presiden Nomor 1 Tahun 1991 tentang kompilasi Hukum Islam pasal 23 ayat 2). Setelah dipenuhi ketentuan syarat-syarat dan rukun perkawinan dalam perundang-undangan perkawinan dan hukum perkawinan Islam, maka wali hakim dapat menikahkan keduanya menjadi pasangan suami istri.

\section{B. METODE PENELITIAN}

Jenis penelitian ini adalah penelitian yang bersifat deskriptif . Pemilihan lokasi dilakukan untuk mengetahui kasus yang terjadi di lokasi penelitian. Penulis memilih Kantor Urusan Agama Kecamatan Ceper Kabupaten Klaten. Di Kantor Urusan Agama kecamatan Ceper Kabupaten Klaten ada peristiwa perkawinan dengan wali hakim sebab wali adlal sehingga hal tersebut menjadi alasan penulis mengadakan penelitian. Sumber data yang dipilih penulis dalam melaksanakan penelitian ini adalah berupa manusia sebagai informan yang dalam hal ini adalah kepala Kantor Urusan Agama Kecamatan Ceper Kabupaten Klaten beserta stafnya, dokumen, arsip, dan literatur-literatur lain yang berhubungan dengan penelitian ini.

Metode analisis yang dipergunakan oleh penulis dalam penelitian ini adalah metode kualitatif. Pengumpulan data dalam penelitian penulis mulai berusaha untuk menarik kesimpulan berdasarkan semua hal bersama-sama dalam reduksi data dan sajian datanya tersebut. Apabila nantinya kesimpulan yang dihasilkan dirasakan masih kurang mantap menurut pertimbangan peneliti, karena masih adanya data yang belum tercakup dalam reduksi dan sajian datanya, maka peneliti akan menggali kembali data-data yang sudah terkumpul dari buku catatan khusus yang memuat data-data yang sudah terkumpul dari lapangan. Seandainya dari buku catatan lapangan tersebut ternyata tidak terdapat data yang diperlukan maka peneliti akan melakukan pengumpulan data kembali untuk mendapatkan data-data khusus atau datadata tambahan yang diperlukan untuk memantapkan hasil peneliti susun, maka sebelum diakhirinya proses pembuatan kesimpulan riset, peneliti akan melakukan kegiatan pendalaman data ke lapangan. 


\section{HASIL DAN PEMBAHASAN}

Manusia adalah makhluk yang paling sempurna di banding dengan makhluk yang lainnya baik sejenis Malaikat, Jin, Hewan, maupun Tumbuhan karena manusia dilengkapi dengan nafsu dan akal pikiran. Dalam fungsi nafsu inilah manusia berusaha untuk melestarikan generasinyan dan untuk menjaga iritabilitasnya/ ketahanannya, Maka manusia melakukan kontak hasrat lawan jenis dengan cara melakukan perkawinan.

Fungsi manusia di bekali akal pikiran agar tertata dan tertib untuk melaksanakan tugasnya sebagai pengelolaan/ kholifah di bumi. Dalam pikiran yang sehat manusia dapat memahami kaidah atau peraturan yang telah diperintahkan oleh Allah SWT. dan menyepakati peraturan yang telah disepakati oleh lingkungannya. Dalam melaksanakan tertib bermasyarakat, berbangsa dan bernegara serta patuh dan tunduk terhadap peraturan/ undangundang yang berlaku.

Perkawinan itu bertujuan untuk membina rumah tangga yang sejahtera lahir dan batin serta untuk menjaga keturunan agar jelas asal mula bapak ibunya begitu pula terbina kehidupan bermasyarakat, berbangsa dan bernegara yang teratur, damai dan aman, maka setiap peristiwa perkawinan yang terjadi harus di catatkan ke lembaga yang berwewenang. Adapun dasar dasar dalam perkawinan sebagai berikut:

1. Undang-undang Nomor 1 tahun 1974

a. Pasal 2 ayat 1 dan 2

1) Perkawinan adalah sah, apabila dilakukan menurut hukum masing-masing agamanya dan kepercayaannya itu.

2) Tiap-tiap perkawinan dicatat menurut peraturan perundangundangan yang berlaku.

b. Pasal 6 ayat 1

Perkawinan harus didasarkan atas persetujuan kedua calon mempelai.

2. Peraturan Pemerintah Nomor 9 Tahun 1975 Tentang Pelaksanaan Undang-undang Nomor 1 Tahun 1974. 
a. Pasal 2 ayat 2

Pencatatan perkawinan dari mereka yang melangsungkan perkawinannya menurut agama Islam, dilakukan oleh Pegawai Pencatat Nikah.

b. Pasal 10 ayat 1,2 dan 3

1) Perkawinan dilangsungkan setelah hari ke sepuluh sejak pengumuman kehendak perkawinan oleh Pegawai Pencatat seperti yang dimaksud dalam Pasal 8 Peraturan Pemerintah ini.

2) Tata cara perkawinan dilakukan menurut hukum masingmasing agamanya dan kepercayaannya itu.

3) Dengan mengindahkan tata cara perkawinan menurut masing-masing hukum agama dan kepercayaannya itu, perkawinan dilaksanakan di hadapan Pegawai Pencatat dan dihadiri oleh dua orang saksi.

c. Pasal 11 ayat 1,2 dan 3

1) Sesaat sesudah dilangsungkan perkawinan sesuai dengan ketentuan-ketentuan Pasal 10 Peraturan Pemerintah ini, kedua mempelai menandatangani akta perkawinan yang telah disiapkan oleh Pegawai Pencatat berdasarkan ketentuan yang berlaku.

2) Akta perkawinan yang telah ditandatangani oleh mempelai itu, selanjutnya ditandatangani pula oleh kedua saksi dan Pegawai Pencatat yang menghadiri perkawinan dan bagi yang melangsungkan perkawinan menurut agama Islam, ditandatangani pula oleh wali nikah atau yang mewakilinya.

3) Dengan penandatanganan akta perkawinan, maka perkawinan telah tercatat secara resmi.

3. Peraturan Menteri Agama Republik Indonesia Nomor 11 Tahun 2007 Tentang Pencatatan Nikah.

a. Pasal 2 ayat 1,2 dan 3 
1) Pegawai Pencatat Nikah yang selanjutnya disebut PPN adalah pejabat yang melakukan pemeriksaan persyaratan, pengawasan dan pencatatan peristiwa nikah/rujuk, pendaftaran cerai talak, cerai gugat dan melakukan bimbingan perkawinan.

2) PPN dijabat oleh Kepala KUA.

3) Kepala KUA sebagaimana dimaksud pada ayat (2) menandatangani akta nikah, akta rujuk, buku nikah (kutipan akta nikah) dan/atau kutipan akta rujuk.

b. Pasal 26 ayat $1,2,3$ dan 4

1) PPN mencatat peristiwa nikah dalam akta nikah.

2) Akta nikah ditandatangani oleh suami, istri, wali nikah, saksi-saksi dan PPN.

3) Akta nikah dibuat rangkap 2 (dua), masing-masing disimpan di KUA setempat dan Pengadilan.

4) Setiap peristiwa pernikahan dilaporkan ke kantor administrasi kependudukan di wilayah tempat pelaksanaan akad nikah.

c. Pasal 27 ayat 1 dan 2

1) Buku nikah adalah sah apabila ditandatangani oleh PPN.

2) Buku nikah diberikan kepada suami dan istri segera setelah proses akad nikah selesai dilaksanakan.

4. Peraturan Menteri Agama Nomor 30 Tahun 2005 tentang Wali Hakim.

a. Pasal 1 ayat 2

Wali hakim, adalah Kepala Kantor Urusan Agama Kecamatan yang ditunjuk oleh Menteri Agama untuk bertindak sebagai wali nikah bagi calon mempelai wanita yang tidak mempunyai wali.

b. Pasal 2 ayat 1,2 
1) Bagi calon mempelai wanita yang akan menikah di wilayah Indonesia atau di luar negeri/di luar wilayah territorial Indonesia, tidak mempunyai wali nasab yang berhak atau wali nasabnya tidak memenuhi syarat, atau mafqud (tidak tentu keberadaanya), atau berhalangan, atau adhol, maka pernikahannya dilangsungkan oleh wali hakim.

2) Khusus untuk menyatakan adhalnya wali sebagaimana tersebut pada ayat 1 pasal ini ditetapkan dengan keputusan Pengadilan Agama yang mewilayahi tempat tinggal calon mempelai wanita.

c. Pasal 3 ayat 1

Kepala Kantor Urusan Agama Kecamatan (KUA) dalam wilayah kecamatan yang bersangkutan ditunjuk menjadi wali hakim untuk menikahkan mempelai wanita sebagaimana dimaksud dalam pasal 2 ayat 1 Peraturan ini.

5. Instruksi Presiden RI Nomor 1 Tahun 1991 Tentang Kompilasi Hukum Islam Di Indonesia

Pasal 23. Wali hakim baru dapat bertindak sebagai wali nikah apabila wali nasab tidak ada atau tidak mungkin menghadirkannya atau tidak diketahui tempat tinggalnya atau ghaib atau adhol atau enggan. Dalam hal wali adhol atau enggan maka wali hakim dapat bertindak sebagai wali nikah setelah ada putusan Pengadilan Agama tentang wali tersebut.

Adapun Syarat Perkawinan dalam peraturan perundang undangan adalah :

1. Perkawinan harus didasarkan atas persetujuan kedua calon mempelai.

2. Untuk melangsungkan perkawinan seorang yang belum mencapaiumur 21 (dua puluh satu) tahun harus mendapat izin kedua orang tua.

3. Dalam hal salah seorang dari kedua orang tua telah meninggal dunia atau dalam keadaan tidak mampu menyatakan kehendaknya, maka izin dimaksud ayat (2) pasal ini cukup diperoleh dari orang tua yang 
masih hidup atau dari orang tua yang mampu menyatakan kehendaknya.

4. Dalam hal kedua orang tua telah meninggal dunia atau dalam keadaan tidak mampu untuk menyatakan kehendaknya, maka izin diperoleh dari wali, orang yang memelihara atau keluarga yang mempunyai hubungan darah dalam garis keturunan lurus keatas selama mereka masih hidup dan dalam keadaan dapat menyatakan kehendaknya.

5. Dalam hal ada perbedaan pendapat antara orang-orang yang disebut dalam ayat (2), (3) dan (4) pasal ini, atau salah seorang atau lebih diantara mereka tidak menyatakan pendapatnya, maka Pengadilan dalam daerah hukum tempat tinggal orang yang akan melangsungkan perkawinan atas permintaan orang tersebut dapat memberikan izin setelah lebih dahulu mendengar orang-orang tersebut dalam ayat (2), (3) dan (4) pasal ini.

6. Ketentuan tersebut ayat (1) sampai dengan ayat (5) pasal ini berlaku sepanjang hukum masing-masing agamanya dan kepercayaannya itu dari yang bersangkutan tidak menentukan lain.

7. Perkawinan hanya diizinkan jika pihak pria sudah mencapai umur 19 (sembilan belas) tahun dan pihak wanita sudah mencapai umur 16 (enam belas) tahun..$^{25}$

Penelitian deskriptif dengan menggunakan data sekunder yang dikomparasikan dengan data primer, penulis melakukan penelitian tersebut hasilnya adalah "dasar kewenangan pelaksanaan perkawinan dengan wali hakim di kantor urusan Agama Kecamatan Ceper Kabupaten Klaten terbagi menjadi dua bagian yaitu yang pertama berdasar perundang undangan yang berlaku di Indonesia/hukum positif Seperti UU No 1 Tahun 1974 tentang Perkawinan, PP No. 9/1975 tentang pelaksanaan UU No 1 /1974 dan PMA No 30 Tahun 2005. Tentang Wali Hakim. Dan yang kedua berdasarkan hukum Islam yaitu Qur'an dan Hadits.

${ }^{25}$ Undang-Undang Nomor 1 Tahun 1974 pasal 6 dan 7, Lihat Zaenal Fatah dkk, Himpunan Peraturan Kepenghuluan, (Semarang: Kantor Wilayah kementerian Agama Propinsi Jawa Tengah, 2013), hal. 19. 
Rukun Nikah adalah hakekat dari suatu perkawinan supaya perkawinan dapat dilaksanakan. Rukun Pernikahan tersebut adalah:

1. Calon mempelai pria dan wanita.

2. Wali calon mempelai wanita.

3. Dua orang saksi pria.

4. Ijab, yaitu ucapan penyerahan calon mempelai wanita dari walinya atau wakilnya kepada calon mempelai pria untuk dinikahi. Dan Qobul, yaitu ucapan penerimaan pernikahan oleh calon mempelai pria atau wakilnya.$^{26}$

Perkawinan itu sah apabila dilakukan menurut hukum masing-masing agamanya dan kepercayaannya itu, maka sahnya perkawinan menurut hukum Islam ditentukan antara lain dengan adanya wali nikah. Tanpa wali nikah perkawinan itu tidak sah.

Bagi calon mempelai wanita yang akan menikah di wilayah Indonesia atau di luar negeri/ di luar wilayah territorial Indonesia, tidak mempunyai wali nasab yang berhak atau wali nasabnya tidak memenuhi syarat, atau mafqud (tidak tentu keberadaanya), atau berhalangan, atau adhol, maka pernikahannya dilangsungkan oleh wali hakim. ${ }^{27}$ Wali hakim baru dapat bertindak sebagai wali nikah apabila wali nasab tidak ada atau tidak mungkin menghadirkannya atau tidak diketahui tempat tinggalnya atau ghaib atau adhol atau enggan. Dalam hal wali adhol atau enggan maka wali hakim dapat bertindak sebagai wali nikah setelah ada putusan Pengadilan Agama tentang wali tersebut. ${ }^{28}$

Pelaksanaan Perkawinan Dengan Wali Hakim Menurut Undangundang Nomor 1 Tahun 1974 dan PMA no 30 tahun 2005 tentang wali hakim bagi calon mempelai wanita yang walinya adhol diperlukan penetapan wali adhol dari pengadilan agama sebelum pernikahan dilaksanakan, Secara umum prosedurnya dapat penulis jelaskan sebagai berikut catin datang:

${ }^{26}$ Intruksi Presiden RI Nomor 1 Tahun 1991, Lihat Kompilasi Hukum Islam di Indonesia, (Jakarta: Departemen Agama RI, 2000), Pasal 14, hal. 18.

${ }^{27}$ PMA RI Nomor 30 Tahun 2005 pasal 2 ayat 1. Lihat Zaenal Fatah dkk, Himpunan Peraturan Kepenghuluan, (Semarang: Kantor Wilayah Kementerian Agama Propinsi Jawa Tengah, 2013), hal. 94.

${ }_{28}$ Intruksi Presiden RI Nomor 1 Tahun 1991, Lihat Kompilasi Hukum Islam di Indonesia, (Jakarta: Departemen Agama RI, 2000), Pasal 23. hal. 22. 
1. Ke Kantor Desa/Kelurahan Dengan membawa Foto Copy KK, KTP, Akta Kelahiran, Ijazah Terakhir, Surat nikah orang tua untuk mendapatkan:

a. Surat keterangan untuk nikah (N1)

b. Surat keterangan tentang asal usul (N2)

c. Surat persetujuan calon mempelai (N3)

d. Surat keterangan tentang orang tua (N4)

e. Surat ijin orang tua, umur calon mempelai kurang 21 tahun (N5)

f. Surat keterangan kematian bagi janda/duda mati (N6)

g. Surat keterangan permohonan wali hakim dari Kepala Desa

2. Ke Puskesmas Untuk mendapatkan:

Surat keterangan dokter/Imunisasi TT I bagi calon mempelai wanita

3. Ke Pejabat Berwenang untuk mendapatkan:

a. Ijin kawin bagi TNI/POLRI

b. Penetapan wali hakim bagi calon mempelai wanita yang walinya adhal.

c. Ijin kawin bagi pria umur kurang 19 tahun dan wanita umur kurang 16 tahun.

d. Ijin kawin atau dispensasi bagi perkawinan dilaksanakan kurang dari 10 hari kerja

4. Ke Kantor Urusan Agama untuk:

a. Memberitahukan kehendak nikah dengan membawa surat-surat yang diperoleh dari Desa/Kelurahan, puskesmas dan pejabat yang berwenang.

b. Membawa tanda bukti setoran pencatatan nikah dari bank bagi yang nikah diluar balai nikah

c. Membawa foto copy akta kelahiran, KTP, KK, ijazah terakhir

d. Membawa akta cerai bagi janda/duda

e. Pemeriksaan Nikah 

f. Pengumuman kehendak nikah
g. Mengikuti penasehatan
h. Pencatatan nikah

5. Ke tempat akad nikah untuk pelaksanaan pernikahan (ijab-qabul)
a. Akad Nikah dilaksanakan di Balai Nikah Kantor Urusan Agama
b. Atas permintaan yang bersangkutan/wali, akad nikah dapat dilaksanakan di luar balai nikah
c. Setelah akad nikah pengantin mendapat buku kutipan Akta Nikah.

Adapun khusus prosedur bagi Wali adhol adalah melalui langkah langkah sebagai berikut :

1. Calon pengantin wanita dan catin pria datang ke KUA kecamatan tempat tinggal catin wanita dengan membawa berkas persyaratan pernikahan untuk memberitahukan kehendak nikah.

2. Petugas PPN memeriksa berkas persyaratan catin wanita dan pria untuk validasi atau kesesuaian.

3. Di dalam pemeriksaan PPN tidak terdapat keterangan wali nikah.

4. Kepala KUA memanggil wali dengan surat diupayakan 3x dengan berita acara pemanggilan.

5. Apabila wali nikah tidak hadir catin wanita diberitahu bahwa persyaratan kurang dengan model N8 (Pemeritahuan kurang syarat)

6. Setelah diberitahukan kepada catin wanita kurang syarat dan tidak bisa melengkapi, Kepala Kua menolak dengan menggunakan model N9 (Penolakan berkas persyaratan) untuk mencari penetapan ke pengadilan Agama setempat dalam rangka wali adlal/bangkang.

7. Catin wanita membuat permohonan kepada Pengadilan Agama untuk menetapkan wali adlal.

8. Setelah ada keputusan dari pengadilan Agama Setempat tentang wali adhol dan memerintahkan kepada KUA sebagai wali hakim, Maka 
catin memberikan hasil keputusan Pengadilan Agama tersebut kepada KUA untuk melengkapi berkas persyaratan nikah.

9. Kepala KUA memanggil kepada wali kembali untuk diberitahu bahwa keputusan wali adhol sudah turun.

10. Bilamana Wali nikah tetap tidak hadir, maka dalam waktu 14 hari setelah keputusan Pengadilan Agama, Kepala KUA sebagai wali hakim melaksanakan pernikahan catin tersebut. ${ }^{29}$

Penulis mendapatkan peristiwa wali adhol di KUA Kecamatan Ceper Kabupaten Klaten atas nama catin wanita dengan nama Asmaul Khusna binti waluyo dengan alamat Gatak RT. 01/RW bin 10 Kujon Ceper, Klaten dengan catin pria atas nama Aris Setyo Mawardi bin Suwardi dengan alamat Kulupan, RT 02/RW 10 Kujon, Ceper, Klaten. Dengan wali nikah Waluyo bin Karyo Rejo dengan alamat Semangkak RT 002/RW 001 Desa Sekarsuli, Kecamatan Klaten Utara. Dengan permasalahan wali nikah tidak mau menjadi wali dikarenakan catin wanita biar sukses terlebih dahulu, mapan dalam bekerja.$^{30}$

Analisis penulis prosedur permohonan ke Pengadilan Agama Kabupaten untuk penetapan wali adhol dengan langkah langkah tersebut sudah memenuhi persyaratan. Dan sesuai dengan peraturan perundang undangan yang berlaku di Indonesia.

\section{KESIMPULAN}

Perkawinan merupakan sunnatullah bagi manusia dengan tujuan untuk melestarikan generasi yang akan datang dan kebahagian hidup, agar dalam perkawinan dapat diakui oleh syari'at agama Islam dan diakui oleh negara, maka harus dicatatkan/diadministrasikan supaya tidak terjadi pembauran garis keturunan termasuk jika terjadi perkawinan dengan wali adhol sehingga dasar kewenangan kepala KUA sebagai wali hakim adalah Undang-undang Nomor 1 Tahun 1974 Tentang Perkawinan, Peraturan Pemerintah Nomor 9 Tahun 1975 Tentang Pelaksanaan Undang-undang Nomor 1 Tahun 1974, Peraturan Menteri Agama Nomor 11 Tahun 2007

\footnotetext{
${ }^{29}$ Hasil wawancara dengan Kepala Kua Kecamatan Ceper pada tanggal 25 Nopember 2016

${ }^{30}$ Dokumen persyaratan nikah di KUA Kecamatan Ceper tahun Bulan Agustus 2016
} 
Tentang Pencatatan Nikah dan PMA No 30/2005 tentang Wali Hakim termasuk didalamnya pernikahan yang dilakukan oleh wali yang adhol.

Prosedur pelaksanaan perkawinan oleh kepala KUA sebagai wali hakim terhadap calon mempelai wanita yang walinya adhol menurut PMA No 30 tahun 2005 adalah calon pengantin wanita dan pria datang ke KUA kecamatan tempat tinggal pengantin wanita dengan membawa berkas persyaratan pernikahan untuk memberitahukan kehendak nikah, jika tidak terdapat keterangan wali nikah, Kepala KUA memanggil wali dengan surat diupayakan 3 (tiga) kali dengan berita acara pemanggilan, apabila terpaksa wali nikah tidak hadir, pengantin wanita diberitahu bahwa persyaratan kurang dengan model N8 (Pemeritahuan kurang syarat). Setelah itu kepala KUA menolak dengan menggunakan model N9 (Penolakan berkas persyaratan) agar mencari penetapan ke Pengadilan Agama setempat dalam rangka wali adhol/bangkang. Setelah ada keputusan dari Pengadilan Agama setempat tentang wali adhol dan memerintahkan kepada KUA sebagai wali hakim, maka calon pengantin memberikan hasil keputusan Pengadilan Agama tersebut kepada kepala KUA untuk melengkapi berkas persyaratan nikah, kemudian kepala KUA memanggil kepada wali kembali untuk diberitahu bahwa keputusan wali adhol sudah turun. Bilamana Wali nikah tetap tidak hadir, maka dalam waktu 14 hari setelah keputusan Pengadilan Agama, Kepala KUA sebagai wali hakim melaksanakan pernikahan calon pengantin tersebut. 


\section{REFERENSI}

Ash-Shabuni, M, Nikah, Kenapa Mesti Ditunda?, Bandung: Hikmah Kelompok Mizan, 2004.

Anwar, H. Moch. Risalah Nikah (Hukum Perkawinan Islam), Jakarta: Pustaka Amani, 1989.

Fatah, Zaenal dkk, Himpunan Peraturan Kepenghuluan, Semarang: Kantor Wilayah kementerian Agama Propinsi Jawa Tengah, 2013.

Inpres RI Nomor I Tahun 1991, Kompilasi Hukum Islam Di Indonesia, Jakarta: Departemen Agama RI, 2000.

Kamil, Taufiq, Membina Keluarga Sakinah, Jakarta: Direktorat Jendral Bimbingan Masyarakt Islam Dan Penyelenggaraan haji, 2003.

Musadi, Laporan Tahunan, Sambi: Kantor Urusan Agama Kecamatan Sambi, 2013.

Nawawi, Hadar, Metode Penelitian Bidang Sosial, Yogyakarta: Gajah Mada University Press, 1986.

Poerwadarminta, WJS, Kamus Umum Bahasa Indonesia. Jakarta: Balai Pustaka, 1986.

Rasyid, Sulaiman, Fiqh Islam, Bandung: Sinar Baru. 1964.

Ramulyo, M. Idris, Hukum Perkawinan Islam (Suatu Analisis Dari Undangundang Nomor 1 Tahun 1974 Dan Kompilasi Hukum Islam), Jakarta : Bumi Aksara, 1996.

Rochim, Abd dkk, Fiqih Madrasah Aliyah, Semarang: C.V. Gani \& Son, 2004.

Sulistiyono, Adi, dkk, Jurnal Konstitusi, (Jakarta: Mahkamah Konstitusi Republik Indonesia, 2010), Volume III Nomor 1, hal. 42.

Soenarjo dkk, Alquran Dan Terjemahnya, Jakarta: Departemen Agama RI, 1971.

Sholeh, Ni'am, Asrorun, Fatwa-Fatwa Masalah Pernikahan dan Keluarga, Jakarta: elSAS, 2008, Cet. I. 
Sutopo, HB, Pengantar Penelitian Kualitatif, Surakarta: Litbang UNS, 1988.

Soekanto, Soerjono, Pengantar Penelitian Hukum, Jakarta: UII Press, 1986.

Soemiyati, Hukum Perkawinan Islam dan Undang-undang Perkawinan (Undang-undang Nomor 1 Tahun 1974), Yogyakarta: Liberty. 1982.

Soenaryo, Hukum Adat II, Surakarta: Buku Pegangan Kuliah Fakultas Hukum Universitas Sebelas Maret. 1993.

Yunus, Mahmud, Hukum Perkawinan Dalam Islam, Jakarta: Hidakarya Agung, 1985. 